Geography and the State 


\title{
Geography and the State
}

An Essay in Political Geography

\author{
R. J. JOHNSTON
}

Macmillan Education 
ISBN 978-0-333-28970-9 ISBN 978-1-349-16967-2 (eBook)

DOI 10.1007/978-1-349-16967-2

(C) R. J. Johnston 1982

Softcover reprint of the hardcover 1st edition 1982 978-0-333-28969-3

All rights reserved. For information, write:

St Martin's Press, Inc., 175 Fifth Avenue, New York, NY 10010

First published in the United States of America in 1982

ISBN 978-0-312-32172-7

Library of Congress Cataloging in Publication Data

Johnston, R. J. (Ronald John)

Geography and the state

Bibliography: $p$.

Includes index.

1. Geography, Political. I. Title.

JC319.J638 $1982 \quad 320.1^{\prime} 2 \quad 82-10438$

ISBN 978-0-312-32172-7 
For Rita 


\section{Contents}

Preface

$i x$

1. Geography and the State: an Introduction 1

Sovereignty

The geography of state activity $\quad 4$

Conclusions

2. The State: its Nature and Functions 11

The functions of the state 11

The role of the state $\quad 15$

State actions $\quad 22$

In summary $\quad 26$

3. The Development of the State 28

Predecessors of the modern state 29

The early state $\quad 40$

From feudalism to capitalism and the early to the
modern state

Late capitalism $\quad 59$

Beyond late capitalism $\quad 64$

Conclusion $\quad 65$

4. The State and the Contemporary World-Economy 66

The contemporary world-economy 67

Core, periphery and semi-periphery 73

The state and the core-periphery structure $\quad 79$

The state versus neocolonialism $\quad 81$

The state as ally of neocolonialism $\quad 100$

The changing morphology of the state system $\quad 108$

Conclusions 118

5. The State, its Territory and its People 120

Core, periphery and semi-periphery 123

Nations against the state: secessionist movements $\quad 140$ 


\section{viii Contents}

The state and the economic core-periphery structure 154 The geography of pluralism

The state and the environment

Conclusions

6. The Local State 187

Federations 188

The nature of local government $\quad 190$

Pluralism and the local state $\quad 200$

Local instrumentalism 213

Local managerialism $\quad 222$

Combatting managers and local instrumentalism $\quad 234$

$\begin{array}{ll}\text { The local fiscal crisis } & 248\end{array}$

The local state and local autonomy 254

$\begin{array}{ll}\text { Conclusions } & 260\end{array}$

$\begin{array}{ll}\text { Postscript } & 261\end{array}$

References 263

Index $\quad 281$ 


\section{Preface}

There can be no distinctive political geographical theory but only a political-geographical perspective within the wider context of political economy: there is no subdiscipline of political geography.

$$
\text { P. J. Taylor }
$$

That is the manner in which politics unfold - not by conspiracies and the exercise of personal power but by error, muddle, doubt, instinct, and the free play of human weakness.

P. Jenkins

The origins of this book lie in a concern with the substance of political geography and its contribution to human geography in recent decades. As I became more involved with the literature and research in the field, so I became more certain that political geography was in an arrested state of development, not, as some have claimed, because the quantitative revolution had passed it by, but rather because it had evolved no sensible treatment of the central element in its work - the state. As I have argued elsewhere, both in academic polemic (Johnston, 1980b, 1980d, 1981b) and in major reviews (Johnston, 1981a, 1981g), political geographers have neither developed nor adopted any viable theory of the state, without which their analyses are incomplete. (All of the attempted analyses, and the many descriptions, are based on an implicit theory; almost invariably this is naive and unrealistic.) This book follows on from those pieces, by presenting the outline of a theoretical approach, both to the study of the state and to the study of state actions. It is a contribution to the political geography perspective, not $a$ political geography. 


\section{x Preface}

The basis to this contribution is aptly summarised by the two quotations at the beginning of this Preface. I agree with Taylor that there can be no autonomous political geography, only a geographical perspective on political topics. That perspective focuses on the interrelationships between the state and various geographical distributions and between the state and aspects of the environment. In the search for explanations of those interrelationships, the geographer cannot stay at the level of appearances. His theoretical perspectives must be derived from the field of political economy, which forms the theoretical heart of the social sciences. But these perspectives are insufficient. As argued in this book, they provide theories of the state, its nature and functions, but not of state activity, of how its functions are fulfilled. For the latter, a separate - though not independent - set of theories is required. These are theories - or perspectives at least - of individual (including corporate) decision-making. The quote by Jenkins is perhaps overly sanguine in its view of how the state acts, but it highlights the need to study politicians and bureaucrats in action, muddling through.

The approach of this book, therefore, is set with my own naive realist philosophy of human geography (Johnston, $1980 \mathrm{f}, 1982 \mathrm{f})$. The prime task of the human geographer is to account for the world as he perceives it, with particular reference to spatial variability within that world. The perceived distributions do not explain themselves, however. Searches for explanation must be based on the processes that generate the distributions, and on the decision-making within those processes that produces the particular observed realisations; hence the twin interest here in theories of the state and theories of state action. Within the social sciences, the geographical perspective is very largely an empirical one, but its explanations must be theoretically derived.

This book is in a series entitled 'Critical Human Geography', which is intended to provide 'a critical examination and extension of the concepts and consequences of work in human geography'. The aim of critical sciences as a whole, as described by Held (1980: 319) and derived from the writings of Habermas, 
is to facilitate the process of methodical self-reflection and to dissolve barriers to the self-conscious development of life. An adequate understanding of all social practices, including scientific inquiry, depends ultimately on these sciences: for by disclosing deformations of communication they attempt to restore to men and women a true awareness of their position in history.

The analyses of geography and the state presented here have been undertaken in that spirit. The goal is to encourage geographers to consider the state more deeply than heretofore, through a combination of theoretical speculation and empirical illustration. This is not applied geography in the traditional sense of having some proximate goal of influencing public policy. Rather, it is applied in the sense of suggesting how a fuller understanding can increase awareness - through geographical teaching and writing - of the nature of the state, and thereby inform individual practice with regard to the state in the future. Whether that practice focuses on the achievement of major changes in the state and the mode of production that it supports, whether it is oriented towards short-term reform, or whether both ends can be pursued simultaneously, is a decision for the individual (Johnston, 1981h). The aim of this book is to inform and to stimulate, not to preach and to prescribe.

Academic books can be grouped into five main types. The first are the instructional texts, those which impart a set body of knowledge; in human geography, statistics texts are probably the best examples of these. Closely associated are the second type, the review texts, which synthesise a body of knowledge, and the third, the collections of readings or original essays, which present major statements on particular themes. The fourth type comprises the more eclectic research monographs. Finally, there is the essay, what might be termed the 'academic polemic', which is selective in its treatment of a subject and aims to stimulate further thought and work on a particular topic. Such books are aimed at other academics and at senior students, those who have received the conventional wisdom from the textbooks and 


\section{xii Preface}

are developing their critiques of what has been handed down. This book is presented as such an essay. It is written to stimulate interest in the reality of the state among political geographers and to contribute to the development of their perspective within the social sciences. It is recognisably partial, focusing most of its attention on the state in capitalist societies.

In preparing this essay, I am grateful to Mark Billinge, Derek Gregory and Ron Martin for encouraging me to write it, and to John Winckler and Steven Kennedy for helping in the production process. Pete Taylor has been research companion and constant source of stimulation during the years in which the essay was developing and being written; Derek Gregory and Ron Martin commented on the entire manuscript and made many very useful suggestions for its improvement. To my wife Rita, who decided to read the full draft while convalescent, I am grateful not only for her continuing support but also for her many useful suggestions. And once again Joan Dunn has endured yet another birowritten scrawl and achieved a major transformation. 